\title{
Amebic Liver Abscess in Rat: Morphological Evidence of Innate Immune Modulation by the Sympathetic Nervous System
}

\author{
Absceso Hepático Amebiano en Rata: Evidencia Morfológica de la Modulación \\ de la Respuesta Inmune Innata por el Sistema Nervioso Simpático
}

\begin{abstract}
Martín Humberto Muñoz-Ortega,"**; Daniel Cervantes-García**; Andrés Quintanar-Stephano***; María del Rosario Campos-Esparza*; Mario García-Lorenzana ${ }^{* * * *}$; R. Campos-Rodríguez ${ }^{* * * * *}$; M. G. Rodríguez ${ }^{* * *}$ \& Javier Ventura-Juárez"
\end{abstract}

MUÑOZ-ORTEGA, M. H.; CERVANTES-GARCÍA, D.; QUINTANAR-STEPHANO,A.; CAMPOS-ESPARZA, M. R.; GARCÍALORENZANA, M.; CAMPOS-RODRÍGUEZ, R.; RODRÍGUEZ, M. G. \& VENTURA-JUÁREZ, J. Amebic liver abscess in rat: morphological evidence of innate immune modulation by the sympathetic nervous system. Int. J. Morphol., 33(1):213-221, 2015.

SUMMARY: All organs of the immune system are innervated and almost all neurotransmitter receptors are present on immune cells. We studied the effects of sympathetic innervation in the development of amebic liver abscess (ALA) in rats. Our results showed that lack of sympathetic innervation promote a decrease in size of ALA. We found scarce amoebas, increased the number of neutrophils and a few collagen fibers surrounding the abscess, meanwhile in control group, we observed abscesses areas with typical necrosis including trophozoites and neutrophils. Macrophages were differentially distributed surrounding abscess area in control and vehicle groups, but equally located in and outside of the abscesses in sympathectomized rat. No significant differences were observed on NK cells in analysed groups. In cytokines quantification studies, we observed down-expression of IFN- $\gamma$ and TNF-a, moreover, we found overexpression of IL-10 in sympathectomized and ALA group. In conclusion, our results suggest that elimination of sympathetic nerve fibers in a model rat of amebic liver abscess induces reduction of the innate immune response and presence of amebas through the liver at seven days post-inoculation.

KEY WORDS: Sympathectomy; Rat; E. histolytica; Amebic liver abscess.

\section{INTRODUCTION}

Amebiasis has a worldwide distribution and is caused by Entamceba histolytica. The pathogenesis of amebic liver abscess (ALA) has been studied both in animal models (Ventura et al., 2002; Tsutsumi \& Shibayama, 2006) and in humans by anatomical characteristics (Pérez-Tamayo, 1990). The principal cellular defence against invasion by $E$. histolytica are neutrophils and macrophages (Jarillo-Luna et al., 2002), but it has been observed that the parasite evades the action of neutrophils through inhibiting the respiratory burst, and induce them lysis, caused by cysteine proteinases, serine proteinases and amoebapores (Arbo et al., 1990). Neutrophils and macrophages are gradually replaced by epithelioid cells developing a granuloma, structure organized within 7 days upon infection (Tsutsumi et al., 1984). Mononuclear cells form a defined limit between the parenchyma and the central zone of necrosis, these cells are elongated like-histiocytes and look as epithelioid cells arranged in palisade form, and amoebas are between the palisade and the region of necrosis (Pinilla et al., 2003). Furthermore, it has been found that the amoeba produces factor inhibitor locomotion monocytes (FILM) which in turn inhibits the chemotaxis and chemokinesis of macrophages (Kretschmer et al., 1985). Moreover, it has been suggested that nitric oxide is an amebicidal compound produced by macrophages, at the same time, in susceptible animals it has found a decrease of cytotoxic activity of macrophages correlated with a decreased expression of mRNA for iNOS and TNF- $\alpha$ (Seydel et al., 2000).

\footnotetext{
* Departamento de Morfología, Universidad Autónoma de Aguascalientes, Aguascalientes, México.

** Departamento de Química, Universidad Autónoma de Aguascalientes, Aguascalientes, México.

*** Departamento de Fisiología, Universidad Autónoma de Aguascalientes, Aguascalientes, México.

***** Departamento de Biología de la Reproducción, Universidad Autónoma Metropolitana Unidad Iztapalapa, Ciudad de México, México.

****** Departamento de Bioquímica, Escuela Superior de Medicina, Instituto Politécnico Nacional, Ciudad de México, México.
} 
MUÑOZ-ORTEGA, M. H.; CERVANTES-GARCÍA,D.; QUINTANAR-STEPHANO,A.; CAMPOS-ESPARZA, M. R.; GARCÍA-LORENZANA, M.; CAMPOS-RODRÍGUEZ, R.; RODRÍGUEZ, M. G. \& VENTURA-JUÁREZ, J. Amebic liver abscess in rat: morphological evidence of innate immune modulation by the sympathetic nervous system.Int. J. Morphol., 33(1):213-221, 2015.

As known, all organs of the immune response are innervated by the sympathetic and parasympathetic systems, and almost all immune cells have receptors to neurotransmitters, neuropeptides and hormones (Blalock, 1989). The three-directional communication among the immune, nervous and endocrine systems occur in three ways: i) the neuroendocrine pathway through axis hypothalamuspituitary-adrenal (HPA) that regulates systemic concentrations of cortisol and adrenalin produced by the adrenal glands, which is controlled through corticotrophinreleasing factor (CRF) and adrenocorticotrophic hormone $(\mathrm{ACTH})$; ii) the neural pathway influences the immune function by neurotransmitters and neuropeptides that interact with immune cells (Webster et al., 2002); nor-epinephrine (NE) and neuropeptide Y (NPY) coexist in adrenergic fibres distributed in the lymphoid organs, the NE has activator properties on lymphocyte functions, natural killer (NK) cells and macrophages; the NPY has inhibitory or immunemodulatory functions on the same cells, mainly on NK cell (Elenkov et al., 2000); acetylcholine (efferent parasympathetic via) stimulates cholinergic receptors on immune cells, but only found specific nicotinic receptors mediate anti-inflammatory effects in macrophages; iii) the sensory nerves like vagus provide feedback signals to the central nervous system (CNS) from sites of injury, infection and inflammation through the proinflammatory cytokines TNF, IL-1 and IL-6 (Sternberg, 2006). The ventromedial hypothalamic area sends sympathetic signals to the liver through efferent nerves and release noradrenaline and neuropeptides (Roskams et al., 2004; Uyama et al., 2004).

To further explore the role of sympathetic system in the modulation of innate immunity against amebic invasion, we evaluated the effect of sympathectomy on cytokines production, neutrophils, macrophages and NK cells activation during the development of ALA in a rat resistant model.

\section{MATERIAL AND METHODS}

Animals. The animals were handled in accordance to guidelines of the Committee on Bioethics in Autonomous University of Aguascalientes, which is based with NHI guideline for animal research (Guide for the Care and Use of Laboratory Animals, 2011).

Thirty-six male Wistar rats (100 to $150 \mathrm{~g}$ ) were maintained in a $12 \mathrm{~h}$ light/dark cycle in a temperaturecontrolled room $\left(25^{\circ} \mathrm{C}\right)$. Diet consisted of Purina Chow and water ad libitum throughout the entire experiment. All animals were previously treated with metronidazole (7.5 $\mathrm{mg} / \mathrm{kg}$ daily for 5 days) to eliminate intestinal parasites. For the experiments, rats were distributed in six groups (six animals each): 1) control; 2) control infected with trophozoites; 3) control vehicle (ascorbic acid $0.1 \%$ in phosphates buffer solution $\mathrm{pH} 7.0$ ); 4) control vehicle infected with trophozoites; 5) chemically sympathectomized; and 6) chemically sympathectomized and inoculated with trophozoites.

Chemical sympathectomy. The denervation was initiated by daily intraperitoneal injections of $40 \mathrm{mg} / \mathrm{kg}$ de 6 hydroxydopamine hydrobromide (6-OHDA, Sigma Aldrich) in ascorbic acid $0.1 \%$ in phosphates buffer solution pH 7.0 as vehicle in 15 days.

Amebic culture. The HM1-IMSS E. histolytica trophozoites (virulent fase $\mathrm{V}$ ) were cultured in axenic medium according to the Diamond procedure (Diamond, 1978).

Induction of amebic hepatic abscesses. Control, vehicle and sympathectomized groups were induction of amebic liver abscess $E$. histolytica trophozoites (25-30 x $10^{4}$ amebas per animal) by intrahepatic injection as described by Ventura-Juárez et al. Liver and abscesses weights were determined after euthanization; abscess ratios in relation to total tissue were reported.

Tissue preparation, staining, immunohistochemistry and immunofluorescence. The animals were euthanized with one dose of $2.5 \mathrm{mg} / \mathrm{kg}$ pentobarbital sodium after 7 days of amebic infection. Tissue samples were taken and fixed in formalin $10 \%$ in PBS for histochemical, immunohistochemistry and immunofluorescence techniques. Also, tissue samples were fixed with glutaraldehyde $2.5 \%$ in PBS for Transmission Electron Microscopy procedure.

Histological sections of $5 \mu \mathrm{m}$ were obtained with the microtome (Leica RM 2125RT) for histochemistry, immunohistochemistry and immunofluorescence studies. Slides were hydrated in a graded of alcohols, and after were processed for histochemistry with hematoxylin-eosin (HE) and Masson techniques as described by Manual of Histologic Staining Methods of the Armed Forces (Luna, 1968).

Immunohistochemistry were developed with the next primary antibodies: $(0.02 \mathrm{mg} / \mathrm{ml})$ rabbit anti- $E$. histolytica (Ventura-Juárez et al.); $1.7 \mathrm{mg} / \mathrm{ml}$ rabbit antihuman myeloperoxidase (mpo) (Merck Millipore AB 1224); $0.01 \mathrm{mg} / \mathrm{ml}$ mouse anti rat CD68 (Merck Millipore MAB1435) for $12 \mathrm{~h}$ at $4{ }^{\circ} \mathrm{C}$. Finally, preparations were incubated with Lab Vision Corporation Large Volume 
MUÑOZ-ORTEGA, M. H.; CERVANTES-GARCÍA, D.; QUINTANAR-STEPHANO,A.; CAMPOS-ESPARZA, M. R.; GARCÍA-LORENZANA, M.; CAMPOS-RODRÍGUEZ, R.; RODRÍGUEZ, M. G. \& VENTURA-JUÁREZ, J. Amebic liver abscess in rat: morphological evidence of innate immune modulation by the sympathetic nervous system.Int. J. Morphol., 33(1):213-221, 2015.

Detection System Goat Anti-Polyvalent Biotin-Streptavidin HRP (Thermo Scientific TP060-BN) for $1 \mathrm{~h}$ at room temperature (RT). The peroxidase activity was developed with diaminobenzidine $(1 \mathrm{mg} / \mathrm{ml})$ for $5 \mathrm{~min}$. Control slides were prepared following the same protocol for each antibody except that the primary antibody was substituted by an unspecific antibody (IgG).

For the immunofluorescence studies, first the autofluorescence was eliminated placing the slides for 10 minutes in a solution of $50 \mathrm{mM}$ ammonium chloride in PBS pH 8.0, slides were then washed in PBS for $10 \mathrm{~min}$. The slides were incubated with the primary antibody for $12 \mathrm{~h}(0.02 \mathrm{mg} / \mathrm{ml})$ mouse anti rat NKR-Pl (Merck Millipore MAB3745) in PBS, and washed in PBS-Tween (0.05\%) 3 times. Preparations were incubated with goat anti-mouse IgG tetramethylrhodamine isothiocyanate (TRITC)conjugated (100 mM) (Sigma Aldrich T5393) for $1 \mathrm{~h}$ at 37 ${ }^{\circ} \mathrm{C}$. After incubation, slides were washed 3 times with PBSTween for $10 \mathrm{~min}$. Control slides were prepared following the same protocol for each antibody except that the primary antibody was substituted by an unspecific antibody (IgG). Finally, immune-stained cells were counted and analyzed as previously described. Ultimately, all preparations (three slides each animal) were analyzed at light and fluorescence microscopy using a Zeiss Axioscope 40/40 FL and were processed in Image Pro Plus software version 4.5.1 for each cell type and trophozoites in two areas: a) in the region of the abscess, and b) in surrounding tissue of the abscess. We reported the mean of cells per area unit in square millimetres. Cellular densities were determined as cells $/ \mathrm{mm}^{2}$.

Transmission Electron Microscopy. The procedure for including tissues in LR White Resin (Sigma-Aldrich) was made as described by Ventura et al. We obtained $80 \mathrm{~nm}$ thick slides in a Leica Ultracut microtome (R-GA-D/E-1/ 00); sections were placed on 300 mesh nikel grids, contrasted with $1 \%$ uranyl acetate and $1 \%$ sodium citrate, and observed at Carl Zeiss microscope TEM-910.

Quantification of IFN-g, IL-10 and TNF- $\alpha$. Blood samples were obtained by intracardiac puncture. Serums were analyzed for IFN-g (Biosource), IL-10 (Biosource) and TNF $-\alpha$ (Invitrogen) levels by ELISA method. The enzymatic activity of peroxidase enzyme was measured at 490 nm with Model 550 Microplates Reader (Bio-Rad).

Statistical analysis. Results are presented as the mean \pm standard error of the mean (SEM). Statistical analyses were performed with Prism software version 3.0(GraphPad Software Inc.). Differences were tested between groups using the t-student test and Tukey mean comparison. P values lower than 0.05 are considered statistically significant.

\section{RESULTS}

Effect of sympathectomy on the tissue structure of ALA. After seven days of inoculation of E. histolytica trophozoites, we compared morphological characteristics of ALA between groups. By macroscopic observation, control group presented characteristic yellowish abscesses with purulence, which were heavier $(8.25 \pm 1.31 \mathrm{~g})$ than those in control vehicle inoculated with trophozoites $(6.33 \pm 1.856 \mathrm{~g})$ and chemically sympathectomized and inoculated with trophozoites $(1.66 \pm 0.33 \mathrm{~g})$ (Fig. 1A-a, -b, -c). Significant decreases of abscesses size were observed in chemically sympathectomized and inoculated with trophozoites when compared with both control and vehicle groups (Fig. 1B). Histologically, in control and vehicle groups, the granuloma lesions developed gross collagen fibers (\#) surrounding the necrotic area (*) in abscesses (Fig. 1A-d, -e, -g, -h). However, chemical sympathectomy developed scarce and diffuse collagen accumulation in abscesses (\#) (Fig. 1A-f, -i). Treatment with 6-OHDA in trophozoite inoculated rats produced decrease in size of abscesses and collagen deposition, these results suggested attenuation of inflammatory response during $E$. histolytica infection after depletion of dopaminergic pathway.

Once the diminution of abscesses was evidenced macroscopically, we assessed the invasive capacity of $E$. histolytica in liver after chemical sympathectomy. By immunohistochemical analyses, we quantified the number of trophozoites (arrows, Figs. 2A-a, -b, -c) in and out of the abscesses. In chemical sympathectomy and inoculated groups a remarkable reduction of amoebas number inside and outside of the abscesses were observed $(5 \pm 0.7$ trophozoites $/ \mathrm{mm}^{2}$ and $3 \pm 0.23$ trophozoites $/ \mathrm{mm}^{2}$, respectively), which were significantly reduced when compared to control and vehicle. Control liver rats shown high quantity of amoebas inside and outside of the developed abscesses $\left(8.67 \pm 0.34\right.$ trophozoites $/ \mathrm{mm}^{2}$ and $5 \pm 0.36$ trophozoites $/ \mathrm{mm}^{2}$, respectively) located mainly in necrotic areas (*). No difference was observed after comparison between amoebas number in control and vehicle group (7.8 \pm 1.34 trophozoites $/ \mathrm{mm}^{2}$ and $7.256 \pm 0.845$ trophozoites/ $\mathrm{mm}^{2}$. respectively) (Fig. 2B). Taken together, these results suggest that chemical sympathectomy induced trophozoites to reduce significantly their invasive capacity with evident decrease of fibrosis and granuloma formation.

In order to evaluate the innate immune response, we documented the distribution of neutrophils (mpo-positive cells), macrophages (CD68-positive cells) and NK (NKRP1-positive cells) in the abscesses after seven days of inoculation evolution. We found that immune cells showed 
A

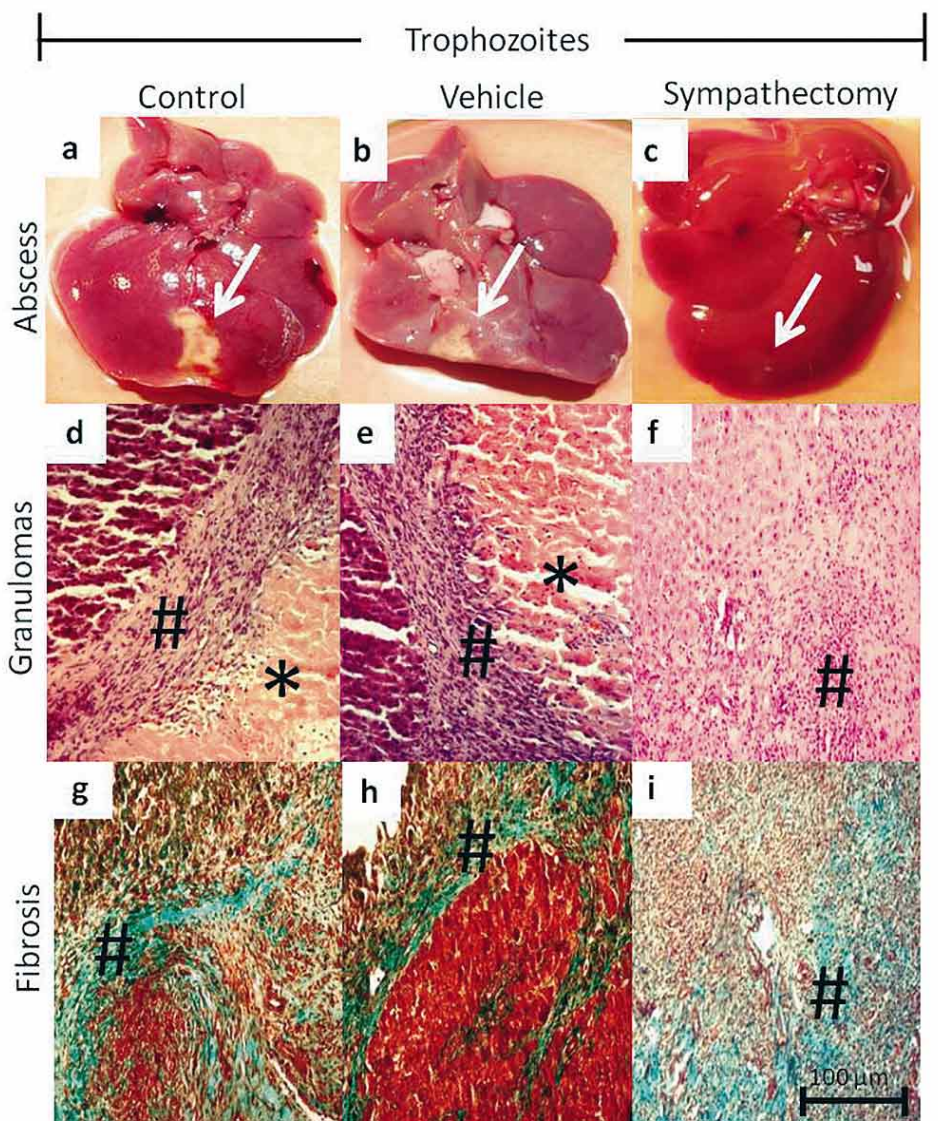

B

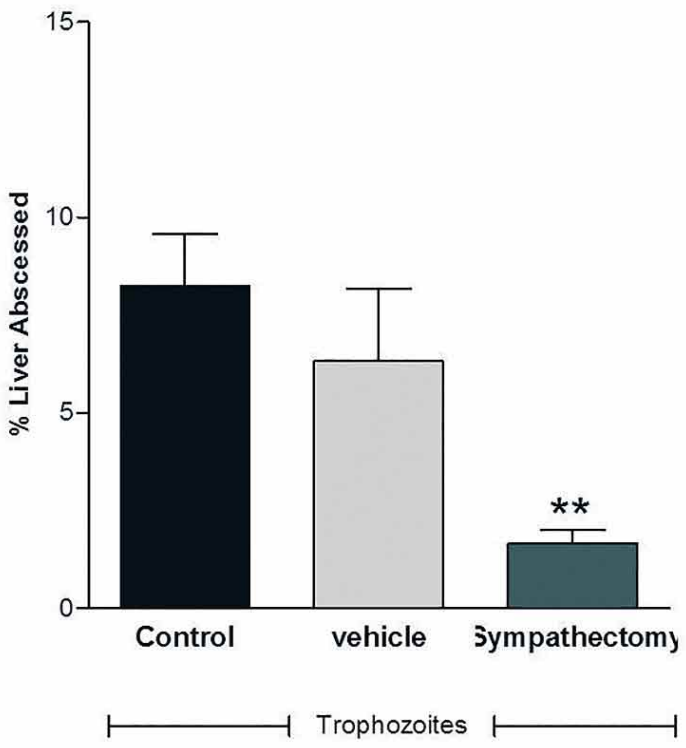

Fig. 1. A) Macroscopic and microscopic analyses of ALA in rats. After 7 days of inoculation, rats developed yellowish abscesses with well-delimited borders (arrow) (a); reduction of abscesses size (arrow) was observed when trophozoites inoculated rats were treated with vehicle (b); however, chemical sympathectomy with 6-OHDA induces size diminution of the abscess (arrow) (c). Necrotic area (*) was encapsulated with collagen fibers (\#), which structures typical border abscesses (d, e). Clearly, sympathectomy with 6-OHDA induced a decrement of collagen fibers (\#) with no evidence of necrosis (f). Abscesses well delimited with walls of gross collagen fibers in control and vehicle infected groups ( $\mathrm{g}, \mathrm{h}$ ); whereas in chemical sympathectomized rats, collagen fibers were diffused (i). B) Liver abscessed area in rats infected with E. histolytica trophozoites with or without chemical sympathectomy. Abscessed liver ratio was significantly reduced after chemical sympathectomy in rats. Data shown are means \pm SEM of at least three rats. $* * \mathrm{P}<0.01$ compared with control group.

different quantities and patterns of distribution. In control and vehicle groups, neutrophils were located mainly in fibrotic area; meanwhile, in chemical sympathectomized and inoculated rats we observed undifferentially distributed neutrophils inside and outside the damaged area (Fig.3 A-a,-b,-c). We observed a significant increment of neutrophils (arrow) (30 $\pm 4.4 \quad$ cells $\left./ \mathrm{mm}^{2}\right)$ in sympathectomized and inoculated group, in comparison to control and vehicle groups $(7.62 \pm 2.3$ and $9.67 \pm 4.41$ cells/ $\mathrm{mm}^{2}$, respectively) (Fig. 3B).

We further determine the presence and distribution of macrophages in ALA. In chemically sympathectomized and infected rats we found that macrophages infiltrated in the inflammatory area. Macrophages (arrow) were distributed along the border of necrotic area $(*)$ and damaged parenchyma in control and vehicle groups (Fig. 3A-d,-e,-f). Besides, the quantity of macrophages was significantly lower in sympathectomized group than control and vehicle (sympathectomized: $80 \pm 2.6$ cells $/ \mathrm{mm}^{2}$; control: $138 \pm 5.6$ cells $/ \mathrm{mm}^{2}$; vehicle: $129.3 \pm 28.3$ cells/ $\mathrm{mm}^{2}$ ) (Fig. 3B).

We examined the effect of the chemical sympathectomy on NK cells infiltration into the ALA. The distribution and quantity of NK did not shown differences in control, vehicle and sympathectomized groups (Fig. 3Ag, -h, -i, 3B). 
A
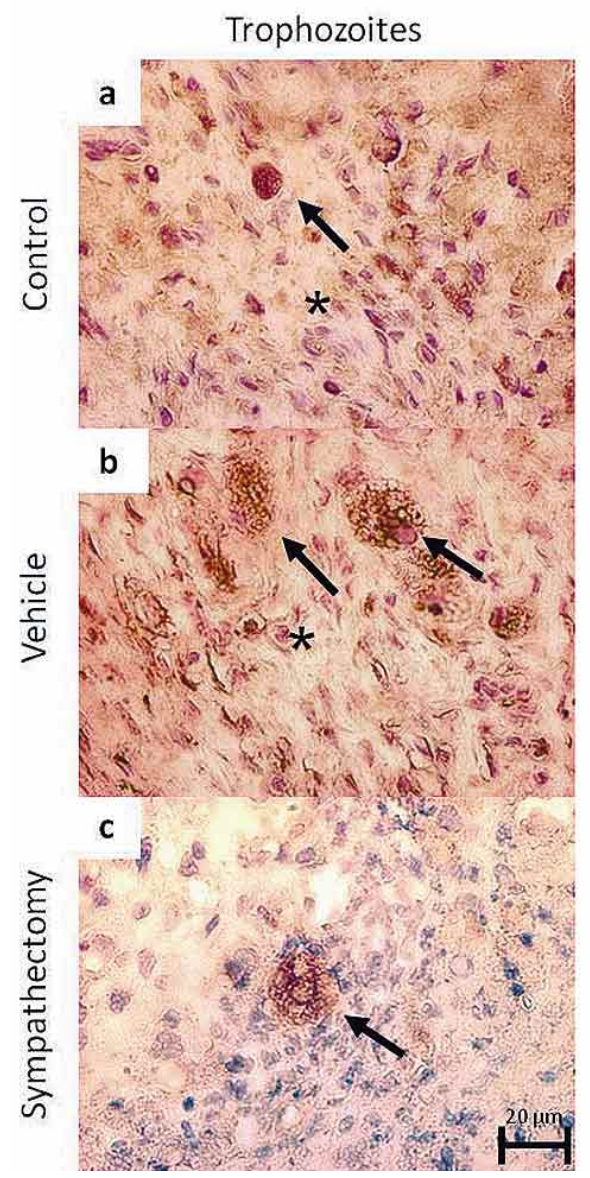

B

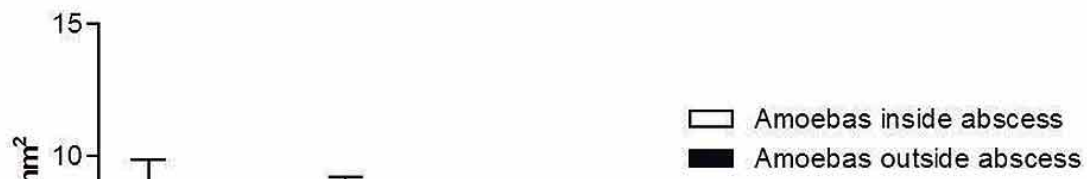

Fig. 2. Immunohistochemistry of rat livers inoculated with $E$. histolytica trophozoites. A) In control and vehicle groups, trophozoites (arrow) appeared invading hepatic tissue with evidence of necrosis $(*)(a, b)$. Necrotic area was reduced in chemically sympathectomized rats; scarce trophozoites were observed (c). B) Trophozoites density in hepatic parenchyma of rats inoculated with E. histolytica. Significantly diminution of trophozoites was observed in chemically sympathectomized rats. Data shown are means \pm SEM of at least three rats. ${ }^{*} \mathrm{P}<0.05$ compared with control group; $\# \mathrm{P}<0.05$ compared with sympathectomized group; \& $\mathrm{P}<0.05$ compared with control $+\mathrm{a}$ group.

We analyzed the interactions between $E$. histolytica and innate immune cells at ultrastructural level. We observed under transmission electron microscopy the amoebas in liver tissue in two zones: abscess region and adjacent hepatic parenchyma. In control rats, we observed viable polymorphic trophozoites (*) typically structured, with high vacuolation and a welldelimited membrane, phagocyted cells (\&) and surrounded by some neutrophils $(\mathrm{N})$, suggesting scarce inflammatory response (Fig. 4A); in hepatic sinusoids (S) we observed viable trophozoites in close contact to a hepathocyte (H) (Fig. 4B). In livers of sympathectomized and inoculated rats, we observed phagocytic active trofozoites $(*)$ with well-delimited membrane (arrow), vacuoles (V) and cytoplasmic granules (head arrow), inside of trophozoite we can see an engulfed leukocyte (L), in close contact to a damaged hepatocytes $(\mathrm{H})$
(Fig. 4C). Eosinophils (E) appeared in the nearness of the damaged area, typically numerous eosinophilic electron-dense granules were presented in cytoplam; furthermore, red blood cells (rbc) demonstrated local vascular congestion (Fig. 4D).

Role of sympathectomy on IFN-g, IL-10 and TNF- $\alpha$ in ALA. Because has been reported that norepinephrine can inhibits the production of cytokines, we wanted to perform quantification of three cytokines to elucidate if chemical sympathectomy modulate the immune response in ALA. IFN$\mathrm{g}, \mathrm{IL}-10$ and TNF- $\alpha$ was analyzed as indicators of inflammatory reaction. Chemically sympathectomized and inoculated rats had significant decrease of IFN-g $(38.25 \pm 1.25$ $\mathrm{pg} / \mathrm{mL})$ contrasted with control $(63.25 \pm 5.5 \mathrm{pg} / \mathrm{mL})$ and Vehicle $(63.5 \pm 1.2 \mathrm{pg} / \mathrm{mL})$ (both $\mathrm{P}<0.05)$ (Fig. $5 \mathrm{~A}$ ). 
A

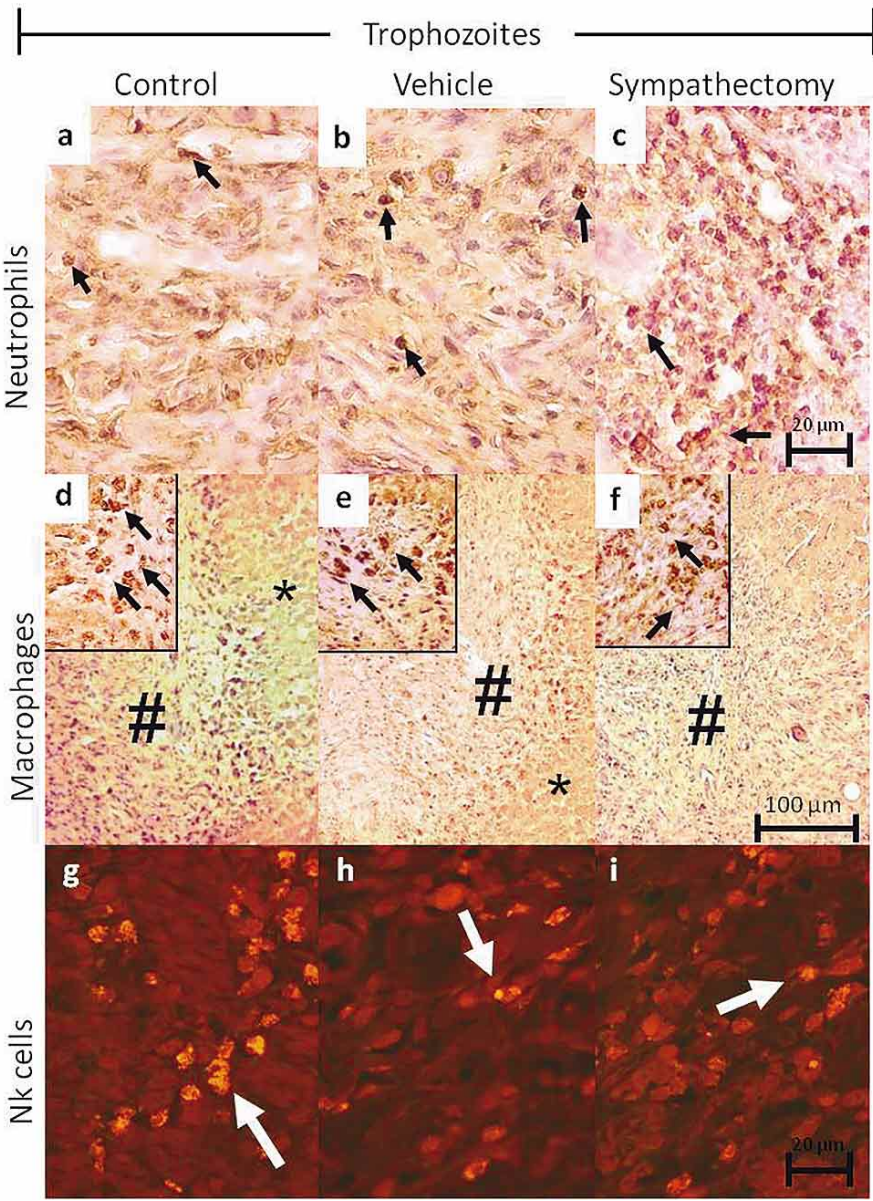

B

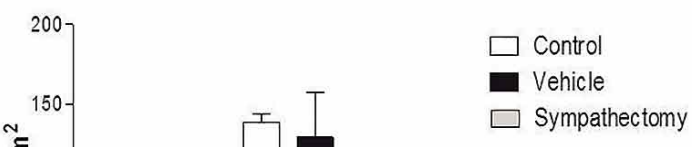

Fig. 3. Immunohistochemistry and immunofluorescence to innate immune response cells in hepatic parenchyma of $\mathrm{E}$. histolytica infected rats. A) Neutrophils (arrows) were located in fibrotic area in control and vehicle groups $(\mathrm{a}, \mathrm{b})$. Moreover, in chemically sympathectomized and infected rats, neutrophils were mainly in the borders of fibrotic area (c). Also, macrophages (arrow) were established offshore of fibrotic borders (\#) around the necrotic area (*) in control and vehicle groups. No differential distribution was observed in chemical sympathectomized rats, macrophages were equally located inside and outside of diffused abscesses. Conversely, no differences in number or distribution of NK cells (white arrows) were observed. B) Significantly increased density of neutrophils was observed when rats were chemically sympathectomized in comparison with control and vehicle. A significant decrease on macrophages after chemical sympathectomy was observed. No significant difference was observed in density of NK cells. Data shown are means \pm SEM of at least three rats. $* \mathrm{P}<0.05$ and $* * \mathrm{P}<0.01$ compared with control group.

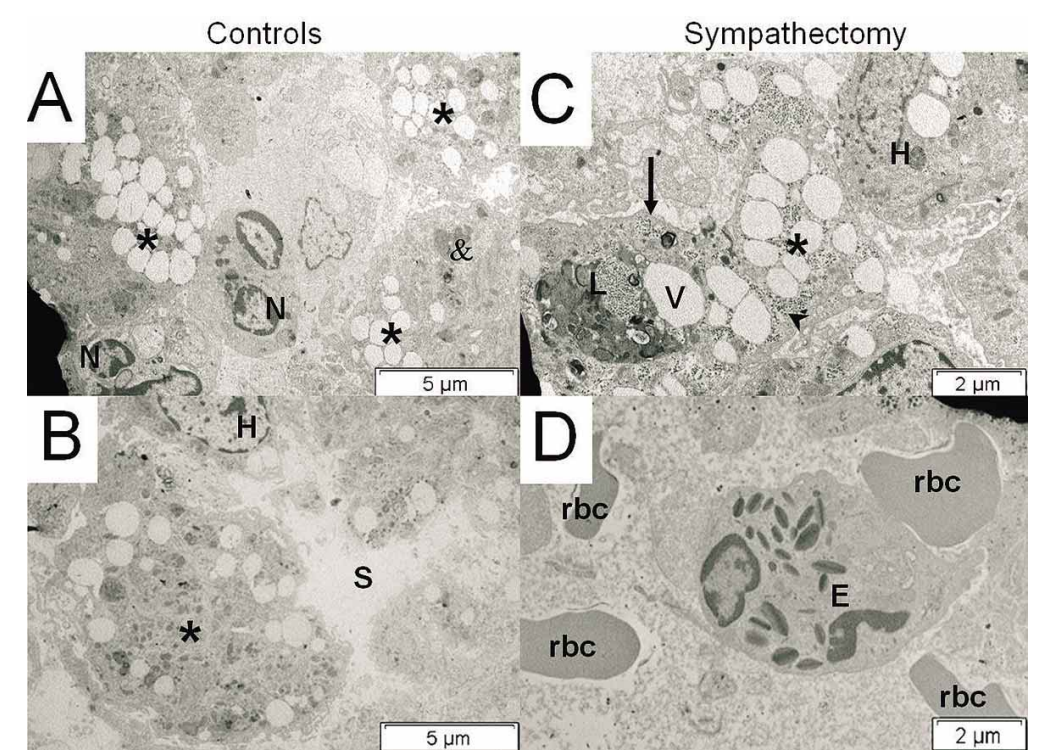

Fig. 4. Transmission electron microscopy appearances of livers inoculated with E. histolytica trophozoites. A) In control inoculated livers, trophozoites are viable $(*)$ and two neutrophils (N) can be observed surrounding one of them, lower right trophozoite had phagocyted one neutrophil (\&). B) A trophozoite (*) is observed inside hepatic sinusoids (S) close to an hepathocyte $(\mathrm{H})$. C) In chemical sympathectomy and inoculated rats, trophozoites $(*)$ still viable with regular cytoplasm, well-defined membrane (arrow) and vacuoles (V), granular cytoplasmic material (arrow head) is deposited among vacuoles, phagocytic activity is demonstrated with a leucocyte engulfed (L). In upper right side, the vacuolization process can be observed when hepatocytes (L) are in contact with trophozoites $(*)$. D) A eosinophil (E) is observed besides to inflammatory process; the association of red blood cells (rbc) demonstrated local vascular congestion. 

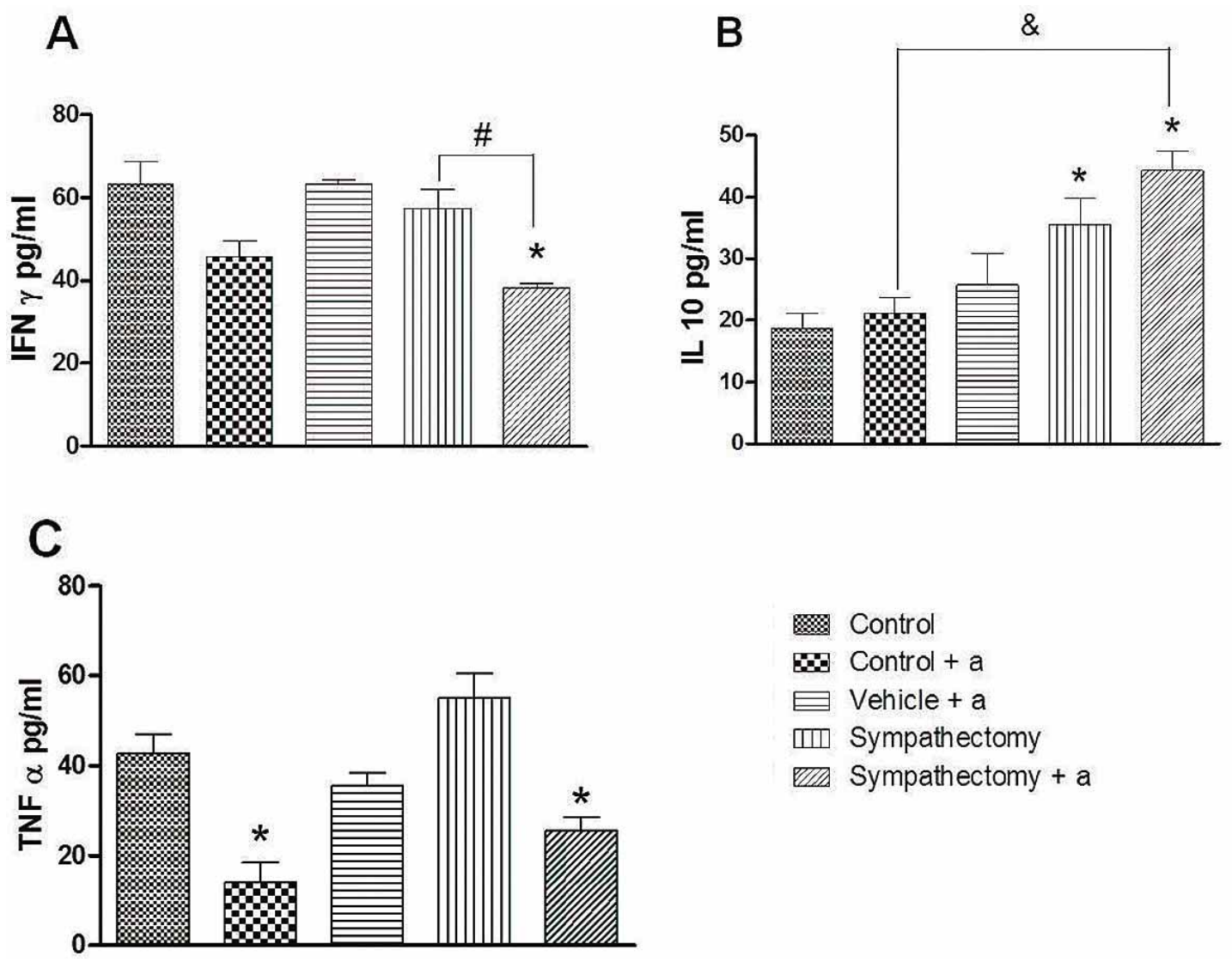

Fig. 5. Determination of cytokines demonstrated the immune modulation of chemical sympathectomy in ALA. A) Significantly decreased production of IFN-g was achieved when E. histolytica infected rats were chemically sympathectomized, in comparison with control and vehicle. B) The production of antiinflamatory cytokine IL-10 was significantly higher in infected rats with chemical sympathectomy. C) Significantly decreased secretion of the proinflammatory TNF-a was achieved in chemical sympathectomy and inoculated rats. Data shown are means \pm SEM of at least three rats. $* \mathrm{P}<0.05$ compared with control group.

Moreover, titers of IL-10 in chemically sympathectomized and inoculated rats were higher $(44.26 \pm 3.1 \mathrm{pg} / \mathrm{ml})$ than those produced in inoculated control $(21.13 \pm 2.5 \mathrm{pg} / \mathrm{ml})$ $(\mathrm{P}<0.05)$. Besides, sympathectomized rats had significant increment of IL-10 (30.51 $\pm 9.4 \mathrm{pg} / \mathrm{ml})$ when compared to control group (18.63 $\pm 2.5 \mathrm{pg} / \mathrm{mL})$ (Fig. 5B). Nevertheless, 6-OHDA did not had effect on TNF- $\alpha$ secretion between chemically sympathectomized $(55.09 \pm 5.5 \mathrm{pg} / \mathrm{ml})$ and control group $(42.72 \pm 4.3 \mathrm{pg} / \mathrm{ml})$. In contrast, during inflammatory process in ALA, chemically sympathectomized and inoculated rats had significantly lower production of TNF- $\alpha(25.57 \pm 2.97 \mathrm{pg} / \mathrm{ml})$ than those showed in control and sympathectomized groups (Fig. 5C). These results indicate that 6-OHDA ameliorated the inflammatory response, moreover, an aditive effect is observed between the immunesupressor property of $E$. histolytica and IL-10 effect on secretion of TNF- $\alpha$.

\section{DISCUSSION}

Although the activation of innate immune response is promoted by two main signaling pathways: pathogenassociated molecular patterns (PAMPs) and those generated for cellular stress; recent data remark the importance of endocrine and neural signaling in the modulation of immune response, this neuroendocrine modulation has effects over adaptive and innate responses (Irwin \& Cole, 2011). Generally, the SNS and PNS inhibited local and systemic immune responses; meanwhile peripheral nervous system extends local immune response. Both systems act together, first to activate and amplify local inflammatory response for contention and elimination of the pathogen, and lately regulation of immune response and tissue repair (Bellinger et al., 2013). 
MUÑOZ-ORTEGA, M. H.; CERVANTES-GARCÍA, D.; QUINTANAR-STEPHANO,A.; CAMPOS-ESPARZA, M. R.; GARCÍA-LORENZANA, M.; CAMPOS-RODRÍGUEZ, R.; RODRÍGUEZ, M. G. \& VENTURA-JUÁREZ, J. Amebic liver abscess in rat: morphological evidence of innate immune modulation by the sympathetic nervous system.Int. J. Morphol., 33(1):213-221, 2015.

It is known that the first line of defense against invasion of E. histolytica trophozoites to colon and others organs, like liver, are principally the innate immunity cells, such as neutrophils, in the early hours of infection. After that, there is recruitment of macrophages and finally lymphocytes resulting in a chronic lesion. This pattern has been observed in susceptible animals, like hamster (Ventura-Juárez et al.; Tsutsumi \& Shibayama). On the other hand, in rat models that are resistant to amoebiasis it is known that immune response eliminate the most of the amebic load at the first $24 \mathrm{~h}$, with high recruitment of neutrophils in acute phase, and lately with increment of macrophages (Pérez-Tamayo et al.; Tsutsumi et al., 1990).

Miura et al. (2001) demonstrated that chemical sympathectomy with 6-OHDA improves survival in mice infected with Listeria monocytogenes, with augmented production of IFN-g, IL-1b, IL-2, IL-4 and IL-6; conversely, noradrenaline inhibited their secretion, but no change was observed in IL-4. Moreover, sympathetic denervation impacted $\mathrm{T}$ cells activity by reduction of reactivity in mice before sensitization with trinitrophenil hapten (Madden et al., 1989). Other studies have shown the influence of SNS on immune response to infection. Straub et al. (2005) analyzed the bacterial load in mice chemically sympathectomized. The selective modification of bacterial load was observed after denervation, with significant reduction and increment of Gram-negative and Gram-positive bacteria, respectively. Furthermore, splenocytes from sympathectomyzed mice had increased production of IFN-g, TNF- $\alpha$ e IL-6, after be challenged with Pseudomona aeruginosa; but, splenocytes stimulated with Staphylococcus aureus, just produced IL-4. Also, sympathectomy in rats by intracerebroventricular administration of 6-OHDA promoted the reduction of proliferation of peripheral T cells, NK cells and splenocytes, increased the cytotoxic CD8+, and diminished production of IL-2 and IFN-g at 7 days after injection (Pacheco-López et al., 2003).

In this report we examined the contribution of SNS in the modulation of immune response in a model of ALA in rat with E. histolytica inoculation. We demonstrated that sympathectomy with 6-OHDA affect the collagen production during the invasion of trophozoites in liver at seven days. Oben et al. (2004) mentioned that the absence of sympathetic fibers induces low activity hepatic stellar cells, allowing diminished collagen synthesis, which accelerates the tissue repair process in a model of hepatic cirrhosis in mice. Based on our results, we propose that the absence of adrenergic activity in the liver during the acute phase of ALA, $E$. histolytica trophozoites activate the recruitment of neutrophils and macrophages, which allow remarkable reduction of amebic load, and lately the regulation of inflammatory process allow tissue repair.
Controversely, our data contrast with previous reports where mentioned that trophozoites can only survive during the first $24 \mathrm{~h}$ post-inoculation (Pérez-Tamayo et al.; Tsutsumi et al., 1990); contrary, we shown alive trophozoites at seven days post-inoculation by immunohistochemistry and electron transmission microscopy in sympathectomized rats.

In conclusion, we argue that the absence of SNS in response to ALA established in rats induce a likely initial increment of the number of neutrophils against $E$. histolytica, which was not able to totally eliminate the parasite at seven day of inoculation; however a diminution of the inflammatory process was obseved and it allows a better liver tissue repair.

MUÑOZ-ORTEGA, M. H.; CERVANTES-GARCÍA, D.; QUINTANAR-STEPHANO, A.; CAMPOS-ESPARZA, M. R.; GARCÍA-LORENZANA, M.; CAMPOS-RODRÍGUEZ, R.; RODRÍGUEZ, M. G. \& VENTURA-JUÁREZ, J. Absceso hepático amebiano en rata: evidencia morfológica de la modulación de la respuesta inmune innata por el sistema nervioso simpático. Int. J. Morphol., 33(1):213-221, 2015.

RESUMEN: Todos los órganos del sistema inmune están inervados y casi todos los receptores para neurotransmisores están presentes en las células de la respuesta inmune. Nosotros estudiamos el efecto de la inervación simpática en el desarrollo del Absceso Hepático Amebiano (AHA) en ratas. Nuestros resultados muestran que la inervación simpática promueve una disminución en el tamaño del AHA. Nosotros encontramos áreas fibróticas bien definidas con algunas amibas, mayor número de neutrófilos y pocas fibras de colágena rodeando el área de daño, mientras que en el grupo control, nosotros observamos áreas con necrosis, trofozoítos y pocos neutrófilos en el área fibrótica. Los macrófagos se observaron distribuidos en el área fibrótica en los animales simpatectomizados, mientras que en los controles encontramos a los macrófagos distribuidos en la periferia del absceso. No se encontró diferencia significativa en la distribución y cantidad de células NK. En el estudio de citocinas nosotros observamos una disminución de IFN-g y TNF- $\alpha$ y un incremento de IL-10 en animales simpatectomizados. En conclusión, nuestros resultados sugieren que la eliminación de las fibras del sistema nervioso simpático en el modelo de AHA en rata, reduce la respuesta inmune innata y persisten amebas en el tejido dañados a los 7 días post-inoculación.

PALABRAS ClaVE: Simpatectomía; Rata; $E$. histolytica; Absceso hepático amebiano.

\section{REFERENCES}

Arbo, A.; Hoefsloot, M.; Ramírez, A. \& Ignacio Santos, J. Entamoeba histolytica inhibits the respiratory burst of polymorphonuclear leukocytes. Arch. Invest. Med. (Mex.), 21 (Suppl. 1):57-61, 1990. 
MUÑOZ-ORTEGA, M. H.; CERVANTES-GARCÍA, D.; QUINTANAR-STEPHANO,A.; CAMPOS-ESPARZA, M. R.; GARCÍA-LORENZANA, M.; CAMPOS-RODRÍGUEZ, R.; RODRÍGUEZ, M. G. \& VENTURA-JUÁREZ, J. Amebic liver abscess in rat: morphological evidence of innate immune modulation by the sympathetic nervous system.Int. J. Morphol., 33(1):213-221, 2015.

Bellinger, D. L.; Millar, B. A.; Perez, S.; Carter, J.; Wood, C.; ThyagaRajan, S.; Molinaro, C.; Lubahn, C. \& Lorton, D. Sympathetic modulation of immunity: relevance to disease. Cell. Immunol., 252(1-2):27-56, 2008

Blalock, J. E. A molecular basis for bidirectional communication between the immune and neuroendocrine systems. Physiol. Rev., 69(1):1-32, 1989.

Diamond, L. S. Axenic cultivation of Entamoeba histolytica. Science, 134(3475):336-7, 1978

Elenkov, I. J.; Wilder, R. L.; Chrousos, G. P. \& Vizi, E. S. The sympathetic nerve--an integrative interface between two supersystems: the brain and the immune system. Pharmacol. Rev., 52(4):595-638, 2000.

Irwin, M. R. \& Cole, S. W. Reciprocal regulation of the neural and innate immune systems. Nat. Rev. Immunol., 11(9):625-32, 2011.

Jarillo-Luna, R. A.; Campos-Rodríguez, R. \& Tsutsumi, V. Entamoeba histolytica: immunohistochemical study of hepatic amoebiasis in mouse. Neutrophils and nitric oxide as possible factors of resistance. Exp. Parasitol., 101(1):40-56, 2002.

Kretschmer, R. R.; Collado, M. L.; Pacheco, M. G.; Salinas, M. C.; López-Osuna, M.; Lecuona, M.; Castro, E. M. \& Arellano, J. Inhibition of human monocyte locomotion by products of axenically grown E. histolytica. Parasite Immunol., 7(5):527-43, 1985

Luna, L. G. Manual of Histologic Staining Methods of the Armed Forces Institute of Pathology. 3rd ed. New York, McGraw-Hill, 1968.

Madden, K. S.; Felten, S. Y.; Felten, D. L.; Sundaresan, P. R. \& Livnat, S. Sympathetic neural modulation of the immune system. I. Depression of T cell immunity in vivo and vitro following chemical sympathectomy. Brain Behav. Immun., 3(1):72-89, 1989.

Miura, T.; Kudo, T.; Matsuki, A.; Sekikawa, K.; Tagawa, Y.; Iwakura, Y. \& Nakane, A. Effect of 6-hydroxydopamine on host resistance against Listeria monocytogenes infection. Infect. Immun., 69(12):7234-41, 2001.

Oben, J. A.; Roskams, T.; Yang, S.; Lin, H.; Sinelli, N.; Torbenson, M.; Smedh, U.; Moran, T. H.; Li, Z.; Huang, J.; Thomas, S. A. \& Diehl, A. M. Hepatic fibrogenesis requires sympathetic neurotransmitters. Gut, 53(3):438-45, 2004.

Pacheco-López, G.; Niemi, M. B.; Kou, W.; Bildhäuser, A.; Gross, C. M.; Goebel, M. U.; del Rey, A.; Besedovsky, H. O. \& Schedlowski, M. Central catecholamine depletion inhibits peripheral lymphocyte responsiveness in spleen and blood. J. Neurochem., 86(4):1024-31, 2003.

Pérez-Tamayo, R.; Becker, I.; Martínez, R. D.; Olivos, A.; Montfort, I. \& Pérez-Montfort, R. The mechanism of natural resistance in the rat to Entamoeba histolytica. Arch. Invest. Med. (Mex.), 21(Suppl. 1):157-61, 1990.
Pinilla, A. E.; López, M. C.; Castillo, B.; Murcia, M. I.; Nicholls, R. S.; Duque, S. \& Orozco, L. C. A diagnostic approach to hepatic abscess. Rev. Med. Chil., 131(12):1411-20, 2003.

Roskams, T.; Cassiman, D.; De Vos, R. \& Libbrecht, L. Neuroregulation of the neuroendocrine compartment of the liver. Anat. Rec. A Discov. Mol. Cell. Evol. Biol., 280(1):910-23. 2004.

Seydel, K. B.; Smith, S. J. \& Stanley, S. L. Jr. Innate immunity to amebic liver abscess is dependent on gamma interferon and nitric oxide in a murine model of disease. Infect. Immun., 68(1):400-2, 2000 .

Sternberg, M. E. Neural regulation of innate immunity: a coordinated nonspecific host response to pathogens. Nat. Rev. Immunol., 6(4):318-28, 2006

Straub, R. H.; Pongratz, G.; Weidler, C.; Linde, H. J.; Kirschning, C. J.; Glück, T.; Schölmerich, J. \& Falk, W. Ablation of the sympathetic nervous system decreases gram-negative and increases gram-positive bacterial dissemination: key roles for tumor necrosis factor/phagocytes and interleukin-4/lymphocytes. J. Infec. Dis., 192(4):560-72, 2005.

Tsutsumi, V. \& Shibayama, M. Experimental amebiasis: a selected review of some in vivo models. Arch. Med. Res., 37(2):210-20, 2006.

Tsutsumi, V.; Mena-Lopez, R.; Anaya-Velazquez, F. \& Martinez-Palomo, A. Cellular bases of experimental amebic liver abscess formation. Am. J. Pathol., 117(1):81-91, 1984.

Tsutsumi, V.; Ramírez-Rosales, A. \& Martínez-Palomo, A. Experimental hepatic amebiasis: acute inflammation in the rat. Arch. Invest. Med. (Mex.), 21(Suppl. 1):233-7, 1990.

Uyama, N.; Geerts, A. \& Reynaert, H. Neural connections between the hypothalamus and the liver. Anat. Rec. A Discov. Mol. Cell. Evol. Biol., 280(1):808-20, 2004.

Ventura-Juárez, J.; Campos-Rodríguez, R. \& Tsutsumi, V. Early interactions of Entamoeba histolytica trophozoites with parenchymal and inflammatory cells in the hamster liver: an immunocytochemical study. Can. J. Microbiol., 48(2):123-31, 2002 .

Webster, J. I.; Tonelli, L. \& Sternberg, E. M. Neuroendocrine regulation of immunity. Annu. Rev. Immunol., 20:125-63, 2002.

\section{Correspondence to:}

Dr. Javier Ventura-Juárez

Departamento de Morfología

Universidad Autónoma de Aguascalientes

Aguascalientes

MÉXICO

Email: jventur@correo.uaa.mx

Received: 27-06-2014 Accepted: 08-01-2015 